\title{
ANALISIS PENDAPATAN PETANI USAHATANI MANGGIS DI DESA SIMPANG SUGIRAN KECAMATAN GUGUAK KABUPATEN LIMAPULUH KOTA
}

\section{ANAL YSIS OF INCOME FARMING OF MANGOSTIN IN SIMPANG SUGIRAN VILLAGE, GUGUAK SUB-DISTRICT, LIMAPULUH KOTA DISTRICT}

\author{
Miftahul Fadhilah*, Dini Rochdiani \\ Prodi Agribisnis, Fakultas Pertanian, Universitas Padjadjaran \\ *Email: mifta12fadhilah@gmail.com \\ (Diterima 12-1-2021; Disetujui 18-1-2021)
}

\begin{abstract}
ABSTRAK
Manggis merupakan salah satu komoditas budidaya yang dibudidayakan di Desa Simpang Sugiran. Permasalahan yang dihadapi petani di Desa Simpang Sugiran adalah penggunaan faktor produksi yang tidak efisien dan terhambatnya ekspor manggis akibat covid-19, yang menyebabkan penurunan pendapatan pada petani manggis. Tujuan penelitian ini adalah menganalisis pendapatan usahatani manggis di Desa Simpang Sugiran. Desain pada penelitian ini menggunakan desain kuantitatif dan teknik penelitian metode survei. Hasil analisis pendapatan didapatkan pendapatan petani manggis di Desa Simpang Sugiran Rp 1.508.207 per pohonnya, sedangkan hasil analisis R/C menunjukkan nilai 5,92 artinya usahatani manggis menguntungkan.
\end{abstract}

Kata Kunci : Manggis, Pendapatan Usahatani

\begin{abstract}
Mangosteen are one of commodities cultivited in Simpang Sugiran Village. The problem faced by farmers in Simpang Sugiran Village are the use of ineffeictient production factors and delay in mangosteen exports due to Covid-19, which cause a decrease in income for mangosteen farmers. The purpose of this study is to analyze the farm income of mangosteen in Simpang Sugiran Village. The design in this study used a quantitative design and survey twchniques research methods. The Result of income analysis obtained by mangosteen farmer in Simpang Sugiran Village Rp. 1.508.207 per tree, while the result of the $R / C$ show a value of 5,92, which means that mangosteen farming is profitable.
\end{abstract}

Keywords : Mangosteen, Farm Income

\section{PENDAHULUAN}

Manggis yang dijuluki sebagai

Queen of Fruit sejak tahun 2000 dan telah dinobatkan sebagai komoditas unggulan berdasarkan Riset Unggulan Strategis Nasional Buah (RUNAS). Laju perkembangan ekspor manggis mencapai $35,6 \%$ setiap tahunnya dan memberikan kontribusi mencapai $37,4 \%$ per tahun.
Berdasarkan data Badan Pusat Statistika volume ekspor manggis pada tahun 2018 mengalami peningkatan yang sangat drastis yaitu dari tahun 2017 sebesar 10082 meningkat menjadi 38071 pada tahun 2018.

Sumatera Barat adalah salah satu sentra manggis Indonesia dengan luas 


\section{ANALISIS PENDAPATAN PETANI USAHATANI MANGGIS DI DESA SIMPANG SUGIRAN \\ KECAMATAN GUGUAK KABUPATEN LIMAPULUH KOTA \\ Miftahul Fadhilah, Dini Rochdiani}

panen pada tahun 20181.274 ha dan

pertumbuhan $5,8 \%$.

Tabel 1. Produksi Manggis Sumatera Barat Berdasarkan Kabupaten dan Kota Tahun 2015-2019

\begin{tabular}{|c|c|c|c|c|c|c|}
\hline \multirow{2}{*}{ No } & \multirow{2}{*}{ Nama Kabupaten/Kota } & \multicolumn{5}{|c|}{ Tahun (Ton) } \\
\hline & & 2015 & 2016 & 2017 & 2018 & 2019 \\
\hline 1 & Pesisir Selatan & $1.339,90$ & 690,40 & 649,80 & $2.144,30$ & $1.210,90$ \\
\hline 2 & Sijunjung & $1.593,20$ & - & 444,50 & 827,60 & $1.736,60$ \\
\hline 3 & Padang Pariaman & $4.043,90$ & - & $6.354,50$ & $6.414,10$ & $5.270,50$ \\
\hline 4 & Limapuluh Kota & $5.033,60$ & - & $5.906,30$ & $3.937,50$ & $10.411,90$ \\
\hline 5 & Tanah Datar & 396,30 & 218,50 & 112,10 & 339 & 225,10 \\
\hline 6 & Solok Selatan & 441,40 & 632,30 & 95,90 & 147,20 & 440,10 \\
\hline 7 & Agam & 3.505 & - & 17.155 & 6.225 & $1.413,10$ \\
\hline 8 & Padang & $2.324,90$ & 76,20 & $1.968,60$ & $1.137,40$ & $5.722,20$ \\
\hline
\end{tabular}

Kabupaten Limapuluh Kota merupakan sentra manggis Provinsi Sumatera Barat dengan produksi manggis sebesar 10.411,90 ton pada tahun 2019 . Pada tahun 2018 juga Sumatera Barat mengekspor manggis perdananya secara langsung ke China sebesar 10.000 ton melalui Kabupaten Limapuluh Kota.

Kecamatan Guguak merupakan salah satu penghasil manggis terbesar yang ada di Kabupaten Limapuluh Kota dengan produksi manggis 1.088 ton pada tahun 2019. Desa Simpang Sugiran merupakan desa dengan produksi manggis tertinggi yang ada di Kecamatan Guguak.

Jika produksi manggis tinggi diikuti dengan harga yang rendah, maka penerimaan petani akan rendah. Begitu pula, seandainya penerimaan petani rendah dan diikuti dengan biaya produksi yang tinggi maka pendapatan petani rendah, dan begitu juga sebaliknya (Dewi \& Qanti, 2018). Pada saat ini harga manggis mengalami penurunan dari awalnya Rp 25.000/kg menjadi Rp 15.000/kg (Kampai, 2020). Dikarenakan pada saat ini dunia sedang dilanda dengan virus yang bernama virus Corona atau Covid-19.

Seperti yang sudah diketahui virus Covid-19 adalah virus yang awalnya ditemukan di negara China sudah tersebar ke seluruh belahan dunia, dan hingga saat ini tanggal 1 Desember 2020 jumlah pasien yang terjangkit virus corona sebanyak 63,2 juta jiwa. Dengan banyaknya pertambahan kasus setiap harinya membuat beberapa negara melakukan kebijakan lockdown.

Dengan adanya kebijakan ini menyebabkan ekpor manggis terhambat dan produksi manggis yang dijual di lokal menjadi meningkat. Sehingga menyebabkan harga manggis menurun dan pendapatan petani juga menurun. 


\section{METODE PENELITIAN}

\section{Tempat dan Objek Penelitian}

Objek penelitian ini adalah pendapatan usahatani manggis di Desa Simpang Sugiran Kecamatan Guguak Kabupaten Limapuluh Kota Provinsi Sumatera Barat. Tempat penelitian dipilih di Desa Simpang Sugiran Kecamatan Guguak Kabupaten Limapuluh Kota Provinsi Sumatera Barat, dengan alasan, bahwa tempat penelitian ini merupakan salah satu sentra penghasil manggis di Sumatera Barat.

\section{Desain Penelitian}

Desain penelitian yang digunakan dalam penelitian ini adalah penelitian kuantitatif. Penelitian kuantitatif merupakan metode yang digunakan pada populasi atau sampel tertentu, analisis data bersifat kuantitatif atau statistik, pengumpulan data menggunakan instrumen penelitian dengan tujuan untuk menguji hipotesis yang telah ditetapkan (Sugiyono, 2019).

\section{Variabel Penelitian}

Variabel yang digunakan dalam penelitian ini adalah sebagai berikut:

1. Produksi merupakan proses budidaya untuk menghasilkan manggis yang memiliki kualitas serta harga jual yang tinggi, diukur berdasarkan berat kilogram (kg).
2. Harga merupakan niali uang yang dibayarkan oleh konsumen kepada penjual atas barang atau jasa yang dibelinya dalam satuan Rupiah (Rp).

3. Biaya produksi manggis, seluruh biaya yang digunakan dalam faktor produksi yang dikeluarkan dalam usahatani manggis, baik secara tunai maupun yang dihitung dalam satu musim tanam yang diukur dengan satuan Rupiah (Rp).

4. Biaya total, biaya yang dikeluarkan selama proses produksi, yang terdiri atas biaya tetap dan biaya variabel. Diukur dalam satuan Rupiah (Rp).

5. Biaya tetap adalah biaya yang dikeluarkan dalam usahatani yang nilainya tetap pada jangka waktu tertentu dan besar kecilnya tidak tergantung dengan ukuran output yang diperoleh. Diukur dengan satuan Rupiah (Rp).

6. Biaya variabel adalah biaya yang digunakan untuk memperoleh faktor produksi berupa benih, pestisida, tenaga kerja dan pupuk. Biaya ini selalu berubah dengan berubahnya keluaran yang dihasilkan dan berhubungan langsung dengan jumlah produksi, diukur dalam satuan Rupiah (Rp). 
7. Penerimaan usahatani adalah nilai produksi yang diperoleh oleh usahatani dari total produk dikalikan dengan harga jual ditingkat petani. Satuan yang digunakan yaitu Rupiah (Rp).

8. Pendapatan usahatani merupakan total penerimaan yang diterima petani setelah dikurangi dengan biaya yang dikeluarkan dalam proses produksi, seperti biaya pembelian pupuk, upah, bibit, sewa lahan, pajak lahan, tenaga kerja, dan biaya penyusutan alat-alat pertanian dalam satu kali musim tanam. Diukur dalam satuan rupiah per tahun (Rp/thn).

\section{Teknik Penarikan Sampel}

Populasi petani manggis di Desa Simpang Sugiran ada 80 orang. Untuk menentukan sampel petani manggis diambil secara metode acak sederhana (sistem random sampling) dengan menggunakan rumus slovin sebagai berikut:

$$
\begin{aligned}
& \mathrm{n}=\frac{N}{1+N(\alpha)^{2}} \\
& \mathrm{n}=\frac{89}{1+89(0,1)^{2}}=47.08 \\
& \mathrm{n}=47
\end{aligned}
$$

Jadi, sampel petani manggis yang dijadikan responden pada penelitian ini yaitu 47 orang.

\section{Teknik Pengumpulan Data}

Teknik pengumpulan data dilakukan melalui wawancara, observasi, kuesioner dan kepustakaan. Wawancara dilakukan pengumpulan data dengan tanya jawab dengan responden agar mendapatkan informasi dan pengetahuan. Survei dilakukan dengan cara mengadakan pengamatan secara langsung terhadap objek yang akan diteliti agar mendapatkan gambaran yang jelas mengenai tempat yang akan diteliti.

Sedangkan cara pengambilan data kuesioner ini dilakukan dengan memberikan para responden seperangkat pertanyaan tertulis untuk dijawab. Data kepustakaan yang didapatkan dalam penelitian ini bisa bersumber dari skripsi, dinas pertanian, jurnal, BPS, outlook tanaman hortikultura, dan media informasi lainnya yang berkaitan dengan penelitian.

\section{Biaya Usahatani}

Biaya usahatani terdiri atas biaya tetap (fixed cost) dan biaya variabel (variable cost) (Soekartawi, 2016).

1. Biaya tetap yaitu biaya yang relatif tetap jumlahnya dan terus dikeluarkan walaupun produks yang diperoleh banyak atau sedikit. 
2. Biaya variabel adalah biaya yang besar kecilnya dipengaruhi oleh jumlah produksi yang diperoleh

Secara sistematis, biaya usahatani dapat dirumuskan sebagai berikut :

$\mathrm{TC}=\mathrm{FC}+\mathrm{VC}$

Keterangan:

$\mathrm{TC}=$ Total Cost $($ Biaya produksi total $)$

$\mathrm{FC}=$ Fixed Cost (Biaya tetap)

$\mathrm{VC}=$ Variable Cost (Biaya variabel)

\section{Penerimaan Usahatani}

Penerimaan usahatani yang diperoleh oleh petani terdiri atas penerimaan secara tunai dan non tunai (Soekartawi, 2016) . Untuk mengetahui penerimaannya dapat menggunakan analisis penerimaan dengan rumus sebagai berikut:

$\mathrm{TR}=\mathrm{P}$. Y

Keterangan:

$\mathrm{TR}=$ Total Revenue $($ Total Penerimaan $)$

$\mathrm{P}=$ Price (Harga jual per unit)

$\mathrm{Y}=$ Jumlah produksi dalam periode tanam tertentu

\section{Pendapatan Usahatani}

Selisih antara penerimaan dan semua biaya yang dikeluarkan merupakan pendapatan (Soekartawi, 2017). Untuk menghitung pendapatan usahatani yang harus diketahui adalah seluruh pengeluaran dan penerimaan selama usahatani dijalankan dalam waktu yang ditetapkan. Untuk menghitung pendapatan usahatani dapat menggunakan rumus:

$\mathrm{Pd}=\mathrm{TR}-\mathrm{TC}$

Keterangan:

$\mathrm{Pd}=$ Pendapatan usahatani manggis

$\mathrm{TR}=$ Total penerimaan usahatani manggis

$\mathrm{TC}=$ Total biaya usahatani manggis

\section{Imbangan Penerimaan dan Biaya}

$(\mathrm{R} / \mathrm{C})$

Menurut Soekartawi, (2016), analisis $\mathrm{R} / \mathrm{C}$ digunakan untuk mengetahui efisiensi dan keuntungan usahatani. Jika $\mathrm{R} / \mathrm{C}<1$, maka usaha yang dikakukan secara ekonomi dapat dikatakan tidak efisien dan usaha tersebut tidak menguntungkan. Sedangkan jika R/C $>1$, maka usaha yang dilakukan secara ekonomi dapat dikatakan efisien dan usaha tersebut menguntungkan.

Sedangkan jika $\mathrm{R} / \mathrm{C}=1$, maka kegiatan usaha berada pada kondisi dimana kegiatan usaha tersebut tidak mendapatkan keuntungan maupun kerugian. Untuk menghitung perbandingan antara penerimaan dan biaya secara matematik dapat menggunakan rumus berikut (Soekartawi, 2016):

$\mathrm{A}=\mathrm{R} / \mathrm{C}$ 
Keterangan:

$\mathrm{A}=$ Imbangan Penerimaan dan Biaya

$\mathrm{R}=$ Besarnya penerimaan dalam usahatani $(\mathrm{Rp})$

$\mathrm{C}=$ Besarnya biaya yang di keluarkan dalam usahatani $(\mathrm{Rp})$

\section{HASIL DAN PEMBAHASAN}

\section{Karakteristik Responden}

Karakteristik dari petani merupakan data pribadi yang membedakan setiap petani. Karakteristik ini diuraikan berdasarkan umur petani, tingkat pendidikan, pengalaman usahatani, dan status kepemilikan lahan.

Berdasarkan data responden 17 petani berada pada kelompok umur sangat produktif dan 30 petani berada pada usia tidak produktif. Tingkat pendidikan formal sebagian besar responden adalah Sekolah Dasar (SD) yaitu sebanyak 19 orang (41\%) terdapat 1 $(2 \%)$ orang yang tidak menempuh pendidikan, 11 (23\%) orang memempuh pendidikan hingga Sekolah Menengah Pertama, 15 (32\% orang menempuh pendidikan hingga Sekolah Menengah Atas dan $1(2 \%)$ orang menempuh pendidikan hingga Sarjana.

Pengalaman petani dalam berusahatani berbeda-beda. Sebagian besar petani sudah berpengalaman dalam berusahatani, terdapat 21 orang (44\%) petani yang sudah berpengalaman selama lebih dari 20 tahun. 6 orang (13\%) petani memiliki pengalaman $<10$ tahun dan 20 petani memiliki pengalaman 10-20 tahun. Berdasarkan data status kepemilikan lahan seluruh responden adalah milik sendiri.

Menurut Elfadina et al (2019), luas lahan pertanian dibagi menjadi 3 kelompok yaitu petani skala kecil dengan luas lahan $(<0,5)$ ha, lahan skala menengah dengan luas lahan (0,5-1,0 ha), dan skala besar dengan luas lahan $(>1$ ha).

Berdasarkan data penelitian luas lahan petani yang ada di Desa Simpang Sugiran sebagian besar (78\%) yaitu antara 0,5-1 ha, artinya luas lahan petani manggis yang dimiliki termasuk ke dalam lahan dengan skala menengah. Sedangkan untuk luas lahan $<0,5$ ha terdapat $7(15 \%)$ orang dan luas lahan $>1$ terdapat $3(7 \%)$ orang

\section{Analisis Pendapatan Usahatani}

\section{Biaya Total Produksi}

Biaya total yang diperoleh petani manggis di Simpang Sugiran per pohonnya dapat dilihat pad Tabel 2. Ratarata biaya tetap yang dikeluarkan petani yaitu Rp 3.956 per pohon. Sedangkan 
untuk biaya variabel $\mathrm{Rp} 367.838$ per pohon. Sehingga didapatkan rata-rata total biaya produksi yang dikeluarkan petani manggis di Desa Simpang Sugiran adalah $\mathrm{Rp} 371.793$.

Tabel 2. Rata-Rata Total Biaya Produksi Usahatani Manggis di Desa Simpang Sugiran per Pohon

\begin{tabular}{|c|c|c|c|c|c|}
\hline \multirow{2}{*}{ No. } & \multirow{2}{*}{ Komponen Biaya } & \multicolumn{2}{|c|}{ Biaya Produksi } & \multirow{2}{*}{ Total Biaya } & \multirow{2}{*}{$\%$} \\
\hline & & Biaya Tetap & Biaya Variabel & & \\
\hline 1. & Biaya Penyusutan & $\operatorname{Rp} 3.956$ & & Rp 3.956 & $1 \%$ \\
\hline 2. & Pupuk & & $\operatorname{Rp} 81.468$ & $\operatorname{Rp} 81.468$ & $22 \%$ \\
\hline 3. & Tenaga Kerja & & Rp286.370 & Rp 286.370 & $77 \%$ \\
\hline & Jumlah & Rp3.956 & Rp 367.838 & $\operatorname{Rp} 371.793$ & 100 \\
\hline
\end{tabular}

\section{Penerimaan Usahatani}

Menurut Soekartawi (2016), selisih antara penerimaan dan semua biaya merupakan pendapatan usahatani. Apabila pendapatan usahtani tersebut bernilai positif, maka usahatani tersebut menguntungkan. Pendapatan yang diperoleh petani dalam usahatani manggis di Desa Simpang Sugiran dapat dilihat pada Tabel 3 .

Tabel 3. Penerimaan Usahatani Manggis per Pohon

\begin{tabular}{|c|c|c|c|c|}
\hline No & Jenis & $\begin{array}{l}\text { Volume } \\
(\mathrm{kg})\end{array}$ & $\begin{array}{l}\text { Harga } \\
\text { (Rp) }\end{array}$ & $\begin{array}{l}\text { Penerimaan } \\
\text { (Rp) }\end{array}$ \\
\hline 1. & Super & 92 & 20.000 & 1.840 .000 \\
\hline 2. & $\mathrm{BS}$ & 5 & 8.000 & 40.000 \\
\hline & Total & & & 1.880 .000 \\
\hline
\end{tabular}

Jumlah rata-rata produksi manggis di Desa Simpang Sugiran per pohon yaitu $97 \mathrm{~kg}$ dengan harga jual untuk kualitas super adalah Rp 20.000/kg dan untuk kualitas BS Rp 8000/kg.

Berdasarkan informasi dan wawancara dari petani rata-rata $5 \%$ dari total produksi manggis merupakan kualitas BS, sedangkan sisanya 95\% manggis berkualitas super. Sehingga didapatkan penerimaan dari usahatani manggis yaitu Rp 1.880 .000 per pohon.

\section{Pendapatan Ushatani Manggis}

Pendapatan yang diperoleh petani dalam usahatani manggis di Desa Simpang Sugiran dapat dilihat pada Tabel 4. Berdasarkan Tabel 4, dapat dilihat hasil penerimaan usahatani manggis $\mathrm{Rp}$ 1.880.000 dan biaya yang dikeluarkan $\mathrm{Rp}$ 317.793, maka didapatkan pendapatan yang diterima petani manggis $\mathrm{Rp}$ 1.508.207 per pohonnya.

Tabel 4. Pendapatan Usahatani Manggis per Pohon

\begin{tabular}{ccc}
\hline No & Uraian & Jumlah $(\mathrm{Rp})$ \\
\hline 1. & Biaya Total & 371.793 \\
2. & Penerimaan & 1.880 .000 \\
3. & Pendapatan & 1.508 .207 \\
\hline
\end{tabular}

\section{Nilai R/C}

Nilai R/C dalam usahatani dapat digunakan untuk melihat apakah kegiatan usahatani yang dilakukan dapat memberikan keuntungan. $\mathrm{R} / \mathrm{C}$ adalah 


\section{ANALISIS PENDAPATAN PETANI USAHATANI MANGGIS DI DESA SIMPANG SUGIRAN \\ KECAMATAN GUGUAK KABUPATEN LIMAPULUH KOTA \\ Miftahul Fadhilah, Dini Rochdiani}

perbandingan antara penerimaan dan biaya (Soekartawi, 2016). Secara sistematik, R/C yaitu:

$$
\begin{aligned}
\mathrm{RC} & =\mathrm{TR}: \mathrm{TC} \\
& =\mathrm{Rp} 1.880 .000: \operatorname{Rp} 317.793 \\
& =5,92
\end{aligned}
$$

Nilai R/C 5,92, maka dengan pengeluaran $\mathrm{Rp} 1$ akan menghasilkan penerimaan Rp 5,92 dan kentungan 4,92, sehingga dapat disimpulkan bahwa usahatani manggis menguntungkan $(\mathrm{R} / \mathrm{C}$ $>1)$.

\section{KESIMPULAN dan SARAN}

\section{Kesimpulan}

1. Rata-rata biaya produksi manggis petani Di Desa Simpang Sugiran paling tinggi per pohonnya terletak pada biaya tenaga kerja yang dengan total biaya $\mathrm{Rp} 286.370$.

2. Rata-rata penerimaan petani manggis di Desa Simpang Sugiran per pohonnya $\mathrm{Rp} 1.880 .000$.

3. Rata-rata pendpatan yang diterima petani di Desa Simpang Sugiran adalah Rp. 1.508.207 per pohonnya

4. Nilai imbangan penerimaan dengan pembiayaan $(\mathrm{R} / \mathrm{C})$ dari petani manggis di Desa Simpang Sugiran adalah 5,29 $>1$, artinya usahatani manggis menguntungkan.

\section{Saran}

1. Diharapkan adanya penyuluhan pemerintah mengenai penggunaan manajemen ushatani dari hulu sampai hilir sehingga sehingga penggunaan fakor produksi dapat efiktas dan efisien dan meningkatkan pendapatan usahatani manggis.

2. Perlunya dilakukan penelitian lebih lanjut mengenai faktor apa saja yang mempengaruhi pendapatan dari usahatani manggis.

\section{DAFTAR PUSTAKA}

BPS. (2016). Volume Ekspor Manggis Indonesia. Badan Pusat Statistika. - (2018). Luas Panen Manggis Provinsi. Badan Pusat Statistika.

(2019). Produksi Manggis Sumatera Barat Berdasarkan Kabupaten Dan Kota. Badan Pusat Statistika.

Deviani, F. (2020). Analisis Pendapatan Dan Faktor-Faktor Yanh Mempengaruhi Produksi Usahatani Buncis Di Desa Cikandang Kecamatan Lembang Kabupaten Bandung Barat. Universitas Padjadjaran.

Dewi, \& Qanti, S. R. (2018). Analisis Kontribusi Pendapatan Usahatani Manggis Terhadap Pendapatan Rumah Tangga Petani Manggis Di Desa Cikalong, Kecamatan Sodonghilir, Kabupaten Tasikmalaya, Jawa Barat. Jurnal Ilmiah Mahasiswa.

Elfadina, E. ., Rasmikyatai, E., \& Saefudin, B. (2019). Analisis Luas dan Status Penguasaan Lahan Petani Mangga Dikaitkan dengan 
Perilaku Agribisnisnya di Kecamatan Cikedung Kabupaten Indramayu. Jurnal Ilmiah Mahasiswa.

Kampai, J. (2020). Geger Virus Corona, Ekspor Manggis Sumbar Terganjal. Www.Detikfinance.Com. https://finance.detik.com/beritaekonomi-bisnis/d-4875220/gegervirus-corona-ekspor-manggissumbar-terganjal
Pratiwi, N. I. (2016). Analisis FaktorFaktor Yang Mempengaruhi Produksi Usahatani Manggis (Garcinia mangostana L.). Universitas Padjadjaran.

Soekartawi. (2016). Analisis Usahatani. Universitas Indonesia. . (2017). Ilmu Usahatani. Universitas Indonesia.

Sugiyono. (2019). Metode Penelitian Kuantitatif, Kualitatid, dan $R \& D$. Alfabeta, cv. 